\title{
Eucharius Rösslin (c 1470-1526) of Germany and the rebirth of midwifery
}

\author{
Peter M Dunn
}

Little is known of Eucharius Rösslin's early life. In 1493 he became an apothecary in Freiburg and 13 years later was elected physician to the city of Frankfurt on Main. From there he moved to a similar post in Worms in the service of Katherine, Princess of Saxony and Duchess of Brunswick and Lüneburg. One of his responsibilities was to examine and supervise the city midwives. These he found to be ignorant, careless, and responsible for many unnecessary deaths. His response, in 1513, was to publish a book on midwifery in Strasburg called Der Rosengarten. The full title, loosely translated was "The rosegarden for pregnant women and midwives." The text was written in German and contained several engravings (fig 1) by Martin Caldenbach, a pupil of Albrecht Dürer (1471-1528). Rösslin dedicated the book to his patron, Katherine. In truth, to a great extent the text was based on the writings of Moschion (circa 6th century AD), who in his turn, had based his own manuscript on the works of Soranus of Ephesus and other writers from classical times. The book was an immediate success. ${ }^{2}$ Emperor Maximillian granted him the copyright for six years.

Rösslin returned to his job in Frankfurt in 1517 and remained in that post until his death in 1526. His son, also named Eucharius Rösslin, succeeded him as town physician. In 1532 he published a Latin translation of his father's book as Du partu Hominis and in 1540 a "studious and diligent clerk," Richard Jonas, retranslated this edition into English with the title "The Byrth of Mankynde" or "The Woman's Book". He re-dedicated the book to "the most gracious Lady Quene Katheryne" (the 5th wife of Henry VIII) with the comment: “... it is nowe so plainly set forth that the simplest Mydwyfe which can reade maye both understand for her better instruction and also other women that have need of her helpe.” In 1545 a new and amended edition was published by a physician, Dr Thomas Raynalde. By now the Rosengarten had been translated into all the

University of Bristol Department of Child Health

Southmead Hospital Bristol BS10 5NB P M Dunn

Correspondence to: Professor Peter Dunn.

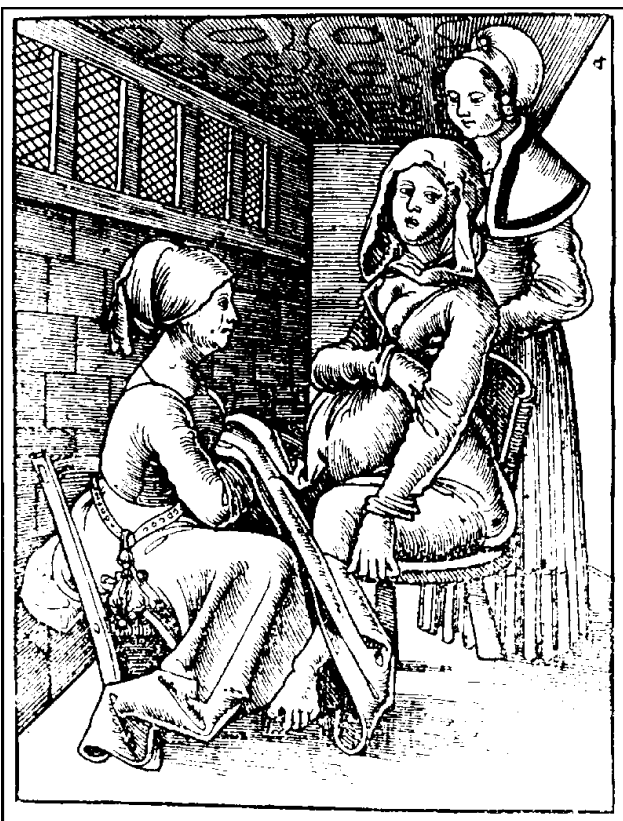

Figure 1 Woman on the delivery stool (from Der Rosengarten, 1513).

profound influence on the practice of midwivery during the 16 th and 17 th centuries.

The following extracts from the 1540, 1545, and 1560 editions give the flavour of the book ${ }^{3}$ :

On the management of normal childbirth

"Now when the woman perceiveth the Matrix or Mother to waxe laxe and loose, and to be dissolved, and that the humours issue foorth in great plenty, then shall it be meete for her to sit downe, leaning backward, in manner upright; for which purpose in some regions (as in France and Germanie) the Midwives have stooles for the nonce, which being but low, and not high from the ground, be made so compassewise and cave or hollow in the middest, that they may be received from underneath which is looked for, and the backe of the stoole leaning backward, receiveth the backe of the woman. The fashion of the which stoole, is set in the beginning of the Byrth figures hereafter." (fig 1).

"And when the time of labour is come, in the same stoole ought to be put many clothes or crows in the backe of it, the which the 
midwife may remove from one side to another, according as necessity shall require. The Midwife her selfe shall sit before the labouring woman, and shall diligently observe and waite, how much, and after what meanes the child sitrreth itselfe: also shall with hands, first anoynted with the oyle of almonds or the oyle of those white lillies, rule and direct everything as shall seeme best.

Also the midwife must instruct and comfort the party, not only refreshing her with good meate and drinke, but also with sweet words, giving her hope of a good speedie deliverance, encouraging and enstomacking her to patience and tolerance, bidding her to held in her breath as much as she may, also stroking gently with her hands her belly about the Navell, for that helpeth to depress the birth downeward.

But this must the midwife above all things take heede of, that she compell not the woman to labour before the birth come forward, and shew itselfe. For before that time, all labour is in vaine, labour as much as yee list. And in this case many times it cometh to passe, that the party hath laboured so sore before the time, that when she should labour indeed, her might and strength is spent before in vaine, so that shee is not now able to helpe her selfe, and that is a perillous case."

\section{On the rupturing of the forewaters}

"(When the bag of membranes appears,) then maye ye knowe that the labour is at hand. If the bag do not burst of its own accord it shalbe the Mydwyfes part and office, with the nayles Easely and gentellye to breake and rent it, or yf that may not conveniently be done, then rayse up betwene your fyngers a peece of it, and cut it with a payre of shieres, or a sharpe knyfe, but so that ye hurt not the byrth with the cut."

\section{On the management of abnormal presentation}

"But when the birth cometh not naturally, then must the midwife doe all her diligence and pain (if it may be possible) to turn the birth tenderly with her anointed hands, so that it may be reduced again to a naturall birth. As for example; sometime it chanceth the childe to come the legs and both arms and hands downward, close to the sides, first forthe ... In this case she must do all her pain and tender handling and anointing to receive forth the child, the legs being still close together, ... Howbeit, it were far better (if it may be done by any possible waies or means) that the midwife should turn these legs coming first forth, upwards again by the bellyward, so that the head might descend downward by the back part of the womb, for then naturally again and without perill might it proceed and come forth as the first."

\section{On a woman's short memory}

"For ye shall heare some women in tyme of theyr travayle meued through great payne and intollerable anguyshe, forswere and vowe them selfe, never to companye with a man agayne; yet after the panges be passed, within a short whyle, for entyre love for theyr husbandes, and singular delyte betwene man and woman, they forget both the sorrow passed and that is to come."

\section{On the provision of air and nutrients to the fetus}

"Thorow these (umbilical) Artires, lively spirite and freshe ayre is derived out of the mother into the chylde, wherewith the naturall heate of the chylde is vivified and refreshed. And these two Artires with the foresayde navyll Vayne, when the child is borne, begin to wyther and drye, every day more and more, and become much like a harpstryng, without any hollownesse or cavitie ...

Forbecause that she (Nature) woulde that the pure bloud commyng from the Matrix vaynes, should be made yet purer, she suffereth not the same to entre immediately into the infante, but first useth another meane, and send it into (the) Chorion or the Loope caule where truely it hath a certayne circulation, and another digestion, wherby it is desecate, and clensed very exquisitly, by the diligentis of nature attenuated and fined, and so at laste sent foorth into the infant, leavyng all the grosser part in the spungye bodye of the Loope caule (placenta).”

1 Graham H. Eternal Eve. London: Heinemann Medical Books, 1950.

2 Radcliffe W. Milestones in midwifery. Bristol: John Wright and Sons, 1967

3 Ballantyne JW. The "Byth of Mankynde": its authors, editions and contents. London: Sherratt and Hughes, 1908. 